\author{
Waldemar IZDEBSKI ${ }^{1}$ \\ Zbigniew MALINOWSKI ${ }^{2}$
}

\title{
ANALIZA STANU NUMERACJI ADRESOWEJ W POLSCE I MOŻLIWOŚCI JEJ WYKORZYSTANIA PRZEZ OBYWATELI I ADMINISTRACJE
}

\begin{abstract}
Ewidencja miejscowości ulic i adresów stanowi jeden z najistotniejszych rejestrów referencyjnych w kraju. Rozproszony sposób prowadzenia tego rejestru jest gwarantem powstawania informacji u źródła, ale z drugiej strony stawia wyzwania technologiczne i organizacyjne, które należy uwzględnić w skutecznym funkcjonowaniu tego rejestru w Polsce. Tym bardziej, że z biegiem czasu zainteresowanie adresem, a zwłaszcza jego lokalizacją przestrzenną wzrasta wprost proporcjonalnie do upowszechnienia systemów informacji przestrzennej oraz systemów nawigacji np. w ratownictwie medycznym, obronie cywilnej, czy działaniu instytucji państwowych oczekujących wysokiej dostępności tego rejestru do realizacji własnych celów. Bo trzeba pamiętać, że do adresu możemy przypisać różne informacje, a istniejąca przy adresie informacja przestrzenna o jego lokalizacji daje duże możliwości prezentacji graficznej i analiz przestrzennych związanych $z$ danymi przypisanymi do adresów. Również świadomość społeczeństwa $\mathrm{z}$ roku na rok wzrasta, a wraz z nią rosną również oczekiwania natychmiastowej dostępności aktualnej informacji on-line, również z wykorzystaniem urządzeń mobilnych. Niniejsze opracowanie opisuje aktualny stanu numeracji adresowej wraz ze wskazaniem wyzwań, problemów i barier do pokonania oraz podstawowych obszarów wykorzystania w zakresie działalności obywateli, funkcjonowania instytucji samorządowych i centralnych, a także nietypowych zastosowań, które kształtują się w miarę upowszechnienia numeracji adresowej jako podstawowego przestrzennego rejestru referencyjnego. Przedstawione wnioski opierają się o bogate doświadczenie autorów artykułu w obszarze praktycznego funkcjonowania numeracji adresowej, co wynika $\mathrm{z}$ wykonania w przeciągu kilku ostatnich lat przez firmę Geo-System Sp. z o.o. wdrożeń systemu do prowadzenia numeracji adresowej w ponad 1500 polskich gminach.
\end{abstract}

Slowa kluczowe: numeracja adresowa, EMUiA, SIP, GIS, nawigacja, administracja, punktyadresowe.pl

\footnotetext{
${ }^{1}$ Autor do korespondencji: Waldemar Izdebski, Politechnika Warszawska, Wydział Geodezji i Kartografii, pl. Politechniki 1, 00-661 Warszawa, tel. 22-234-7751, email: w.izdebski@gik.pw.edu.pl

${ }^{2}$ Malinowski Zbigniew, Geo-System Sp. z o.o., ul. Kubickiego 9 lok. 5, 02-954 Warszawa, tel. 22 847-35-80, email: malinowski@geo-system.com.pl
} 


\section{Opis stanu obecnego w zakresie numeracji adresowej}

Wejście w życie ustawy o infrastrukturze informacji przestrzennej [1] wprowadziło szereg zmian w dotychczasowym postrzeganiu rejestrów publicznych, zwłaszcza w kontekście osadzenia ich w przestrzeni. Ustawa, poza treściami zasadniczymi, wprowadziła szereg zmian $\mathrm{w}$ ustawie prawo geodezyjne $i$ kartograficzne [2], również w zakresie prowadzenia rejestru numeracji adresowej. Zgodnie z art. 4 ust 1a ustawy pgik rejestr przyjął nazwę Ewidencja Miejscowości Ulic i Adresów, a rozporzadzenie Ministra Administracji i Cyfryzacji w sprawie EMUiA [3] określiło tryb i zasady techniczne i organizacyjne jego prowadzenia. Ustawodawca nie uniknął niestety szeregu błędów, które wraz z propozycją rozwiązań zostały omówione w pozycji [4]. Dyrektywa INSPIRE i ustawa o IIP ugruntowały kierunek, w jakim od lat zmierzały rejestry przestrzenne. Dodatkowo dzięki dynamicznemu rozwojowi urządzeń związanych $\mathrm{z}$ nawigacją i lokalizacją przestrzenną pojęcie adres we współczesnym społeczeństwie zyskało zupełnie nowe, praktyczne wykorzystanie. Adres przestał być kolejnym numerem w rejestrze, a dzięki przypisaniu mu lokalizacji przestrzennej przez współrzędne geograficzne $(\varphi, \lambda)$, stał się bardzo pomocny w określaniu miejsca $\mathrm{w}$ przestrzeni, które chcemy zlokalizować lub do którego chcemy dotrzeć.

Referat niniejszy stanowi analizę obecnego stanu rzeczy w zakresie numeracji adresowej w Polsce, w kwestii faktycznego prowadzenia rejestrów adresowych w gminach, ich aktualności, zastosowanych rozwiązań technicznych, ale również potencjalnych problemów wynikających ze sposobu prowadzenia rejestru, jego rozproszenia, czynników ludzkich i wadliwych uregulowań prawnych. Opisane również zostaną potencjalne sposoby rozwiązania pojawiających się problemów oraz najistotniejsze oczekiwania wobec numeracji adresowej od obywateli i administracji zarówno samorządowej, jak też centralnej.

\section{Prowadzenie numeracji adresowej na poziomie gminy}

Obecnie 2478 gmin i miast realizuje zadania z zakresu samorządu gminnego, w tym m.in. obowiązek prowadzenia rejestru ewidencji miejscowości ulic i adresów zgodnie z art. 47a ustawy PGIK. Warto dodać, że rozporządzenie MAiC nakłada na gminy obowiązek prowadzenia tej ewidencji w formie elektronicznej już od 3 lutego $2013 \mathrm{r}$.

Firma Geo-System Sp. z o.o. zajmuje się informatyzacją rejestrów adresowych już ponad 10 lat posiadając obecnie już ponad 1500 wdrożeń. Działania te autorzy referatu realizowali dużo wcześniej niż uchwalono obecne zapisy prawne w tym zakresie. 


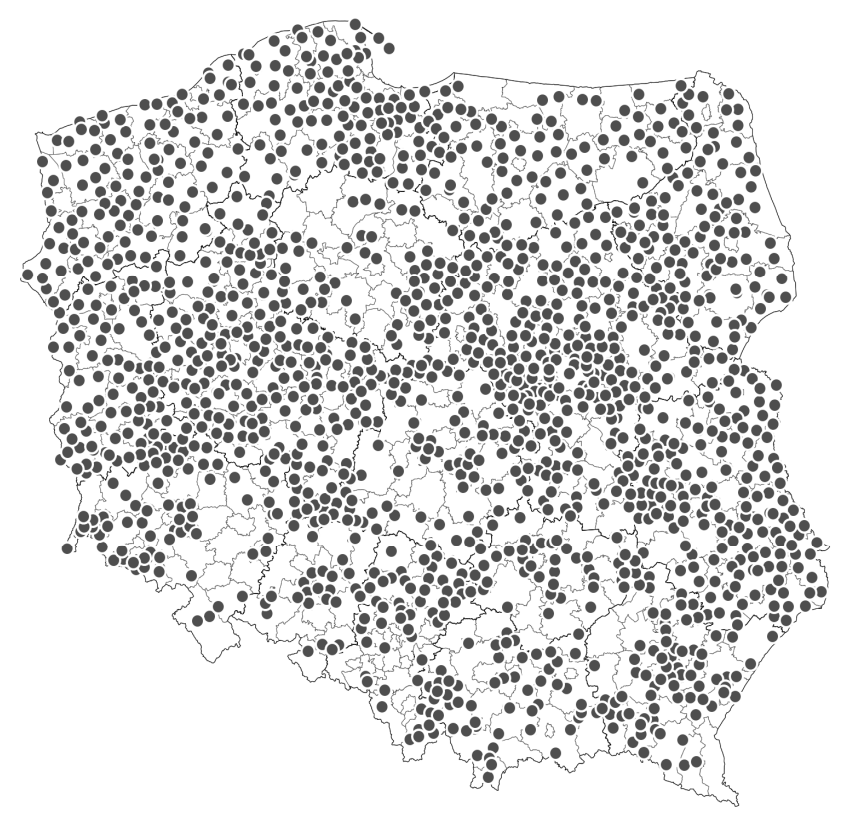

Rys. 1. Gminy wykorzystujące system iMPA do prowadzenia rejestrów adresowych

Fig. 1. Map of municipalities using iMPA software for address register

Dzięki tak imponującej liczbie wdrożeń firma dysponuje największym wachlarzem doświadczeń i znajomością specyfiki polskich gmin, gdyż z systemu korzystają jednostki od małych gmin po miasto stołeczne Warszawa. Każde wdrożenie obejmuje dostarczenie oprogramowania, pozyskanie danych $\mathrm{z}$ materiałów analogowych do bazy numerycznej, weryfikację z innymi rejestrami (więcej w rozdziale 4), szkolenie użytkowników oraz uruchomienie gminnego portalu mapowego dającego natychmiastowy dostęp dla wszystkich użytkowników Internetu do powstałego zbioru.

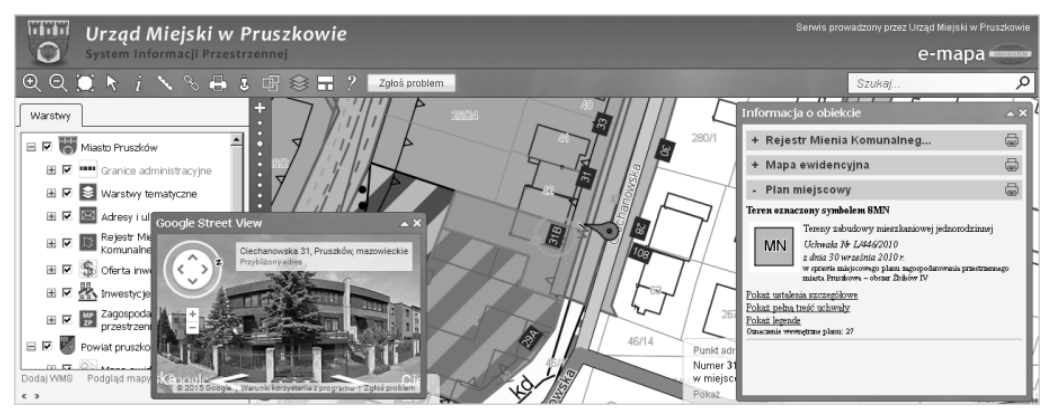

Rys. 2. Portal mapowy miasta Pruszków w technologii eGmina

Fig. 2. Pruszków map portal using eGmina software 
Niezależnie od portalu mapowego udostępniane są również usługi sieciowe wynikające $\mathrm{z}$ wymogów ustawy o IIP, które mogą być wykorzystane w innych portalach i systemach informatycznych.

Rozwiązując problem prowadzenia baz adresowych część gmin podjęło decyzję o przystąpieniu do projektu TERYT2 realizowanego ze środków unijnych przez Główny Urząd Geodezji i Kartografii. W ramach tego projektu zaplanowano opracowanie $i$ bezpłatne udostępnienie aplikacji służącej do prowadzenia rejestru EMUiA. Jak się okazuje, większość samorządów pozostała na etapie podpisania porozumienia i nie korzysta w bieżącym funkcjonowaniu urzędu $\mathrm{z}$ tego narzędzia, mimo iż GUGiK przeprowadził kosztowne szkolenia z obsługi aplikacji, a nawet $\mathrm{w}$ ramach kolejnych wydatków opracował nową aplikację, gdy poprzednia okazała się mało funkcjonalna. $Z$ perspektywy czasu można wskazać, że idea wytworzenia aplikacji, zaoferowania jej nieodpłatnie (chociaż podatnik miał znaczny wkład w dotychczasowe wydatki związane z tym i powiązanymi projektami) nie sprawdziła się. Przyczyny takiego stanu rzeczy należy szukać $\mathrm{w}$ organizacji prowadzenia tego rejestru $\mathrm{w}$ strukturze rozproszonej i niezależności samorządów szczebla gminnego od GGK.

Oczywiście należy również podnieść wątpliwość, wielokrotnie wyrażaną w publicznej korespondencji przez Waldemara Izdebskiego, dotyczącą zasad równości i sprawiedliwości gospodarczej, gdyż nienaturalnym jest konkurowanie na rynku $\mathrm{z}$ firmami komercyjnymi podmiotu finansowanego $\mathrm{z}$ pieniędzy publicznych. Tym niemniej największym problemem prawidłowego i sprawnego funkcjonowania numeracji adresowej w Polsce jest doprowadzenie do sytuacji, w której faktycznie każdy samorząd, z zastosowaniem dowolnych narzędzi prowadzi i aktualizuje na bieżąco rejestr numerów porządkowych, tak, aby mógł on być włączony do Krajowej Infrastruktury Informacji Przestrzennej. Znacznie zwiększy to dostępność zasobu, a jednocześnie poszerzy grupę docelową podmiotów zainteresowanych informacją adresową.

\section{Wyzwania i problemy oraz sposoby ich rozwiązania}

Funkcjonowanie jakiegokolwiek rejestru o znaczeniu krajowym w strukturze rozproszonej na poziomie gminnym stanowi nie lada wyzwanie organizacyjne. Jest to niemal 2500 samorządnych jednostek, w każdej z nich tematyka adresów zajmuje się co najmniej jeden pracownik (w większych miastach niejednokrotnie jest to 2-4 osób). Ogromną pracą w takim układzie jest już zbudowanie relacji, w ramach których obieg informacji jest szybki i skuteczny, a zadania egzekwowalne. Do tego dochodzi wsparcie dla władz gmin i budowanie świadomości tego, jak ważny stał się rejestr numeracji adresowej i dlaczego tak istotne jest, aby przykładać do jego funkcjonowania należytą uwagę. Oczywiście na to nakłada się również rozwiązywanie problemów związanych z infrastrukturą sieciową lub sprzętową. Nagromadzenie tych czyn- 
ników oraz mimowolnej różnorodności samorządów utrudnia ujednolicenie, a nawet $\mathrm{w}$ miarę skuteczne udostępnienie rejestru numeracji adresowej.

$\mathrm{W}$ zakresie integracji baz danych numeracji adresowej ustawodawca przewidział rozporządzeniem RM z dnia 10 stycznia 2012r. [5] funkcjonowanie Państwowego Rejestru Granic i Powierzchni Jednostek Podziałów Terytorialnych Kraju (w skrócie PRG), w ramach którego GUGiK centralnie gromadzi informacje o adresach aktualizowaną na podstawie baz gminnych dzięki wykorzystaniu usług sieciowych.

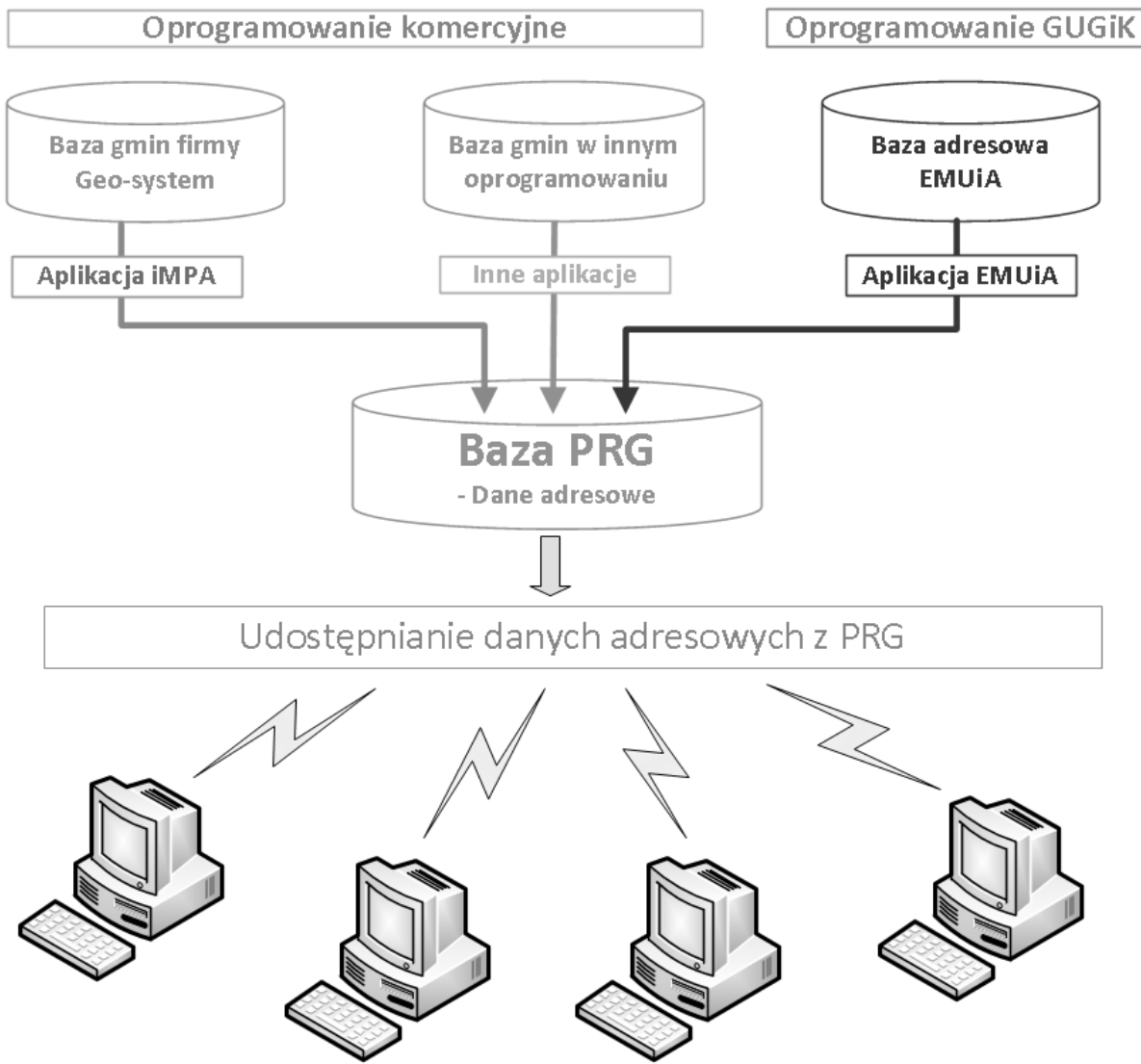

Rys. 3. Schemat zasilania i wykorzystania rejestru PRG [6]

Fig. 3. Usage schema of PRG registry

Koncepcja wydaje się słuszna, gdyż ma gwarantować dostępność kompletnej numeracji adresowej w skali Polski na żądanie dowolnego wnioskodawcy. Jak zawsze jednak, z nieokreślonych przyczyn teoria rozminęła się z praktyką. Wytyczne i specyfikacja usług zasilania PRG dla systemów informatycznych zostały opracowane i przekazane twórcom oprogramowania na spotkaniu, które 
GGK zorganizował $\mathrm{w}$ dniu 28.02.2013r. Jednak dopiero w połowie grudnia 2014r. usługa produkcyjna została faktycznie uruchomiona. Najprawdopodobniej gdyby nie to 20-miesięczne opóźnienie, na chwilę obecną wszystkie prowadzone $\mathrm{w}$ systemach teleinformatycznych bazy adresowe trafiłyby już do PRG, a nowopowstałe trafiały tam od razu po oddaniu do użytku. Tymczasem, przez pół roku funkcjonowania usługi zasilania PRG wielokrotnie występują awarie i przerwy techniczne. Firma Geo-System Sp. z o.o. za każdym razem zwraca się w korespondencji publicznej do zarządcy usługi PRG - Głównego Geodety Kraju z monitem, prośbą o reakcję i potraktowanie sprawy jako priorytetowej. Mimo zaistniałych trudności, wykorzystując działającą z przerwami usługę dotychczas zasilono niemal 600 kompletnych baz adresowych, co w obliczu ponad 1500 wdrożeń jest oczywiście liczbą niezadowalającą.

Taki stan usługi zasilania PRG ma wpływ na jakość i kompletność zbioru PRG w zakresie numeracji adresowej, a tym bardziej na jego aktualność. Dodatkowo kwestia sposobu udostępniania danych ze zbioru PRG w postaci aktualizowanych co jakiś czas paczek danych udostępnianych na stronie CODGiK (Centralny Ośrodek Dokumentacji Geodezyjnej i Kartograficznej) zamiast usługi sieciowej np. WFS (Web Feature Service) również ogranicza dostęp online do aktualnych danych.

Firma Geo-System Sp. z o.o. już w 2010 roku na potrzeby funkcjonowania dynamicznie rosnących zbiorów adresowych opracowała własną usługę ULA (usługa lokalizacji adresów), która została natychmiast doceniona nagrodą Innowacyjnej Usługi w konkursie Krajowych Liderów Innowacji i Rozwoju w 2010r. ULA bazuje na usługach sieciowych zwracających współrzędne dla wskazanego adresu. Co istotne usługa nie ogranicza się do funkcjonowania jedynie w ramach wdrożeń systemu iMPA, ale ma charakter otwarty i pozwala na włączenie baz adresowych prowadzonych $\mathrm{w}$ innych systemach. Jednocześnie może być wykorzystywana do podłączenia baz adresowych do narzędzi mapowych - zarówno portali internetowych, jak i oprogramowania typu desktop. 


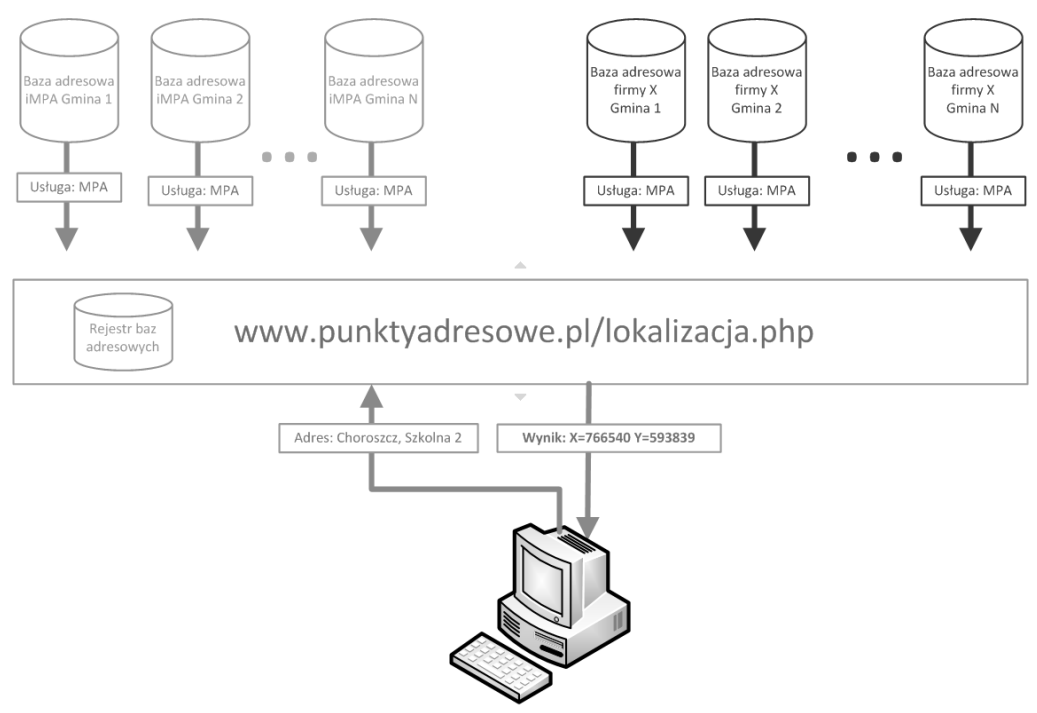

Rys. 4. Schemat funkcjonowania usługi ULA [8]

Fig. 4. Usage schema of ULA service

Usługa od początku funkcjonowania jest z powodzeniem wykorzystywana m.in. w powiatowych portalach mapowych, pozwalając tym samym na integrację danych adresowych bezpośrednio ze źródła ich pochodzenia.

Przywołując współpracę samorządów szczebla gminnego i powiatowego należy krótko przypomnieć o problemie niezadowalającej dostępności ewidencji gruntów i budynków, przynajmniej w zakresie publikacji informacji związanych z działkami i budynkami.

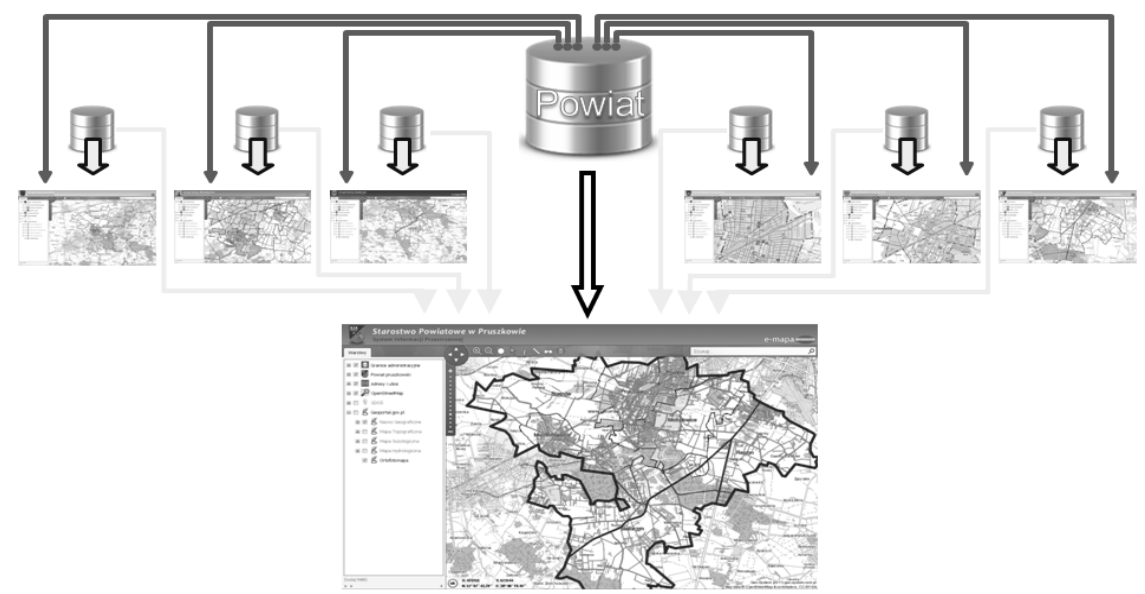

Rys. 5. Schemat współpracy pomiędzy powiatem a gminami [7]

Fig. 5. Cooperation schema including municipalities and district 
$\mathrm{Na}$ chwilę obecną nieco ponad $40 \%$ powiatów udostępnia usługi sieciowe które mogą i powinny być wykorzystane przez samorządy gminne m.in. do realizacji swoich zadań publicznych - prowadzenie numeracji adresowej, miejscowych planów zagospodarowania przestrzennego, bazy decyzji o warunkach zabudowy, czy rejestru mienia komunalnego [6].

\section{Mechanizmy budowania jakości rejestru adresowego}

Doświadczenie wdrożeniowe wyraźnie pokazuje, że największy wpływ na jakość i aktualność informacji adresowej ma, poza dokładną analizą materiału źródłowego, korelacja $\mathrm{z}$ innymi rejestrami publicznymi przechowującymi adresy lub bazującymi na adresach.

Weryfikacja bazy adresowej w oparciu o wykaz adresów używanych w ewidencji ludności jest działaniem znacznie zwiększającym wiarygodność danych. Przede wszystkim pozwala na wyeliminowanie braków dotyczących adresów używanych powszechnie przez mieszkańców gminy, którzy nie zgłosili się do pracownika gminy odpowiedzialnego za numerację adresową i nie otrzymali stosownego zawiadomienia o nadaniu adresu. Niejednokrotnie takie porównanie pozwala również na wyłapanie oczywistych błędów w rejestrze ewidencji ludności, dotyczących budynków wyburzonych czy osób błędnie zameldowanych.

Mechanizmy powiązania informacji o liczbie osób zameldowanych $\mathrm{z}$ adresem $\mathrm{i}$ jego lokalizacją przestrzenną otwierają nowe możliwości w wytwarzaniu nowej jakościowo informacji. Przede wszystkim użytkownik gminny uzyskuje proste narzędzie do przeprowadzania precyzyjnych analiz demograficznych odniesionych do adresu. Co istotniejsze, mechanizmy analiz są oparte o aktualny stan numeracji adresowej. Jednym ruchem myszy można uzyskać informację o liczbie zameldowanych osób dla wybranego obszaru bezpośrednio z mapy. Kontakty z użytkownikami oprogramowania wskazują na duże zainteresowanie tymi mechanizmami, nie tylko z punktu widzenia zarządzania gminą, ale również w zakresie obrony cywilnej. 


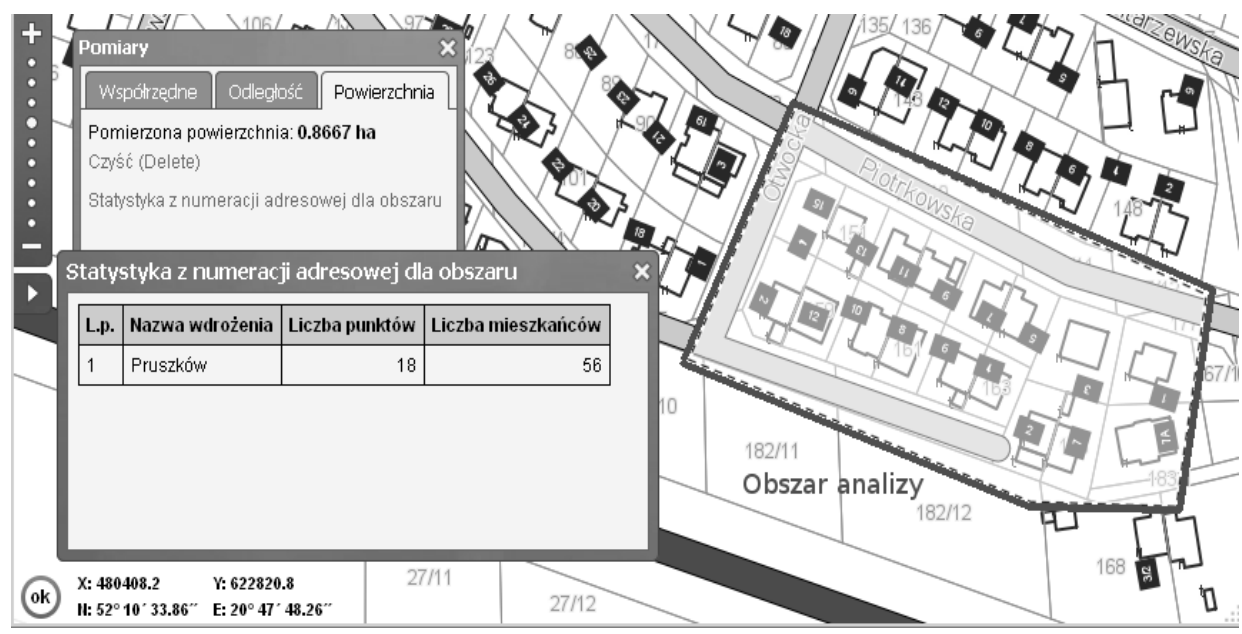

Rys. 6. Przykład analizy demograficznej powiązanej z adresami

Fig. 6. Example of demographic analysis using addresses

Wraz z rosnącą świadomością społeczeństwa w zakresie systemów informacji przestrzennej obserwujemy tendencję, w której użytkownicy portalu mapowego posiadając wiedzę dotyczącą swojego najbliższego terenu bardzo szybko są w stanie wychwycić ewentualne błędy (np. dotyczące adresu swojego lub sąsiada) i chętnie zgłaszają je do urzędu prosząc o poprawienie nieścisłości. Jest to nieoceniona pomoc dla pracownika gminy, który nie ma szans wychwycić tego rodzaju rozbieżności bez wizyty w terenie. W celu ułatwienia tej komunikacji w portalu mapowym gminy udostępniono prostą funkcję zgloś problem, pozwalającą przesłać informację opisową o błędzie wraz z lokalizacją przestrzenną wskazaną z użyciem mapy.

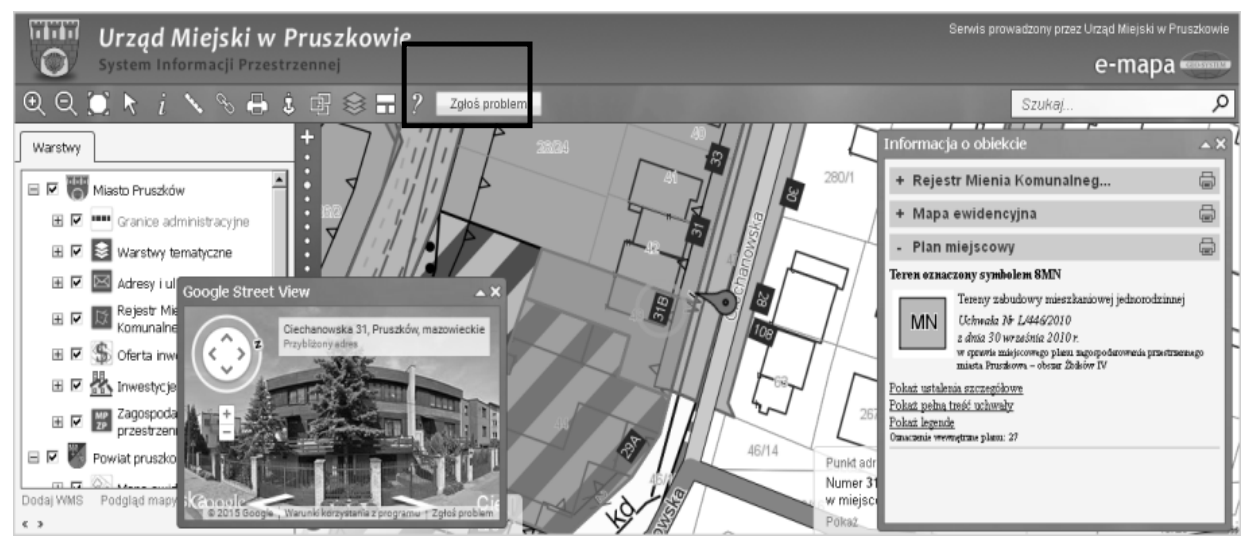

Rys. 7. Przycisk funkcji “zgłoś problem” w portalu mapowym Pruszkowa

Fig. 7. Illustration of typical "report a problem" function in eGmina system 


\section{Wykorzystanie numeracji adresowej przez obywateli, insty- tucje samorządowe i rządowe}

Z punktu widzenia obywatela adres jest podstawowym narzędziem lokalizacji miejsca lub zdarzenia. Analiza statystyk wykorzystania poszczególnych mechanizmów szukania z funkcjonujących 1500 wdrożeń wykazuje, że 80\% wszystkich wyszukiwań dotyczy ulicy i adresu. Działki ewidencyjne, lokalizacja MPZP (miejscowe plany zagospodarowania przestrzennego) na podstawie wykazu i szukanie obiektów zainteresowania (POI - points of interest) stanowi łącznie pozostałe $20 \%$. Dlatego tak ważne jest posiadanie aktualnej warstwy numerów adresowych i ulic do prawidłowego funkcjonowania systemów informacji przestrzennej dowolnego szczebla. Bez możliwości odnalezienia miejsca po adresie każdy system niezależnie od poziomu skomplikowania i zawartości warstw informacyjnych oferuje jedynie ułamek swoich możliwości.

Ciągły wzrost sprzedaży urządzeń mobilnych typu smartfon czy tablet siłą rzeczy wytwarza w społeczeństwie śmiałość do wykorzystywania w codziennym życiu tych narzędzi, zwłaszcza jeśli one ułatwiają i przyspieszają uzyskanie wiarygodnej informacji. Również bazy adresowe za pośrednictwem gminnego portalu mapowego dostępne są online - wystarczy w teren zabrać urządzenie z dostępem do internetu. Obywatel może skorzystać z ogólnodostępnych mechanizmów szukania (analogicznie jak w portalu na komputery stacjonarne), ale również wykorzystując wbudowany GPS uzyskać swoją pozycję i wyświetlić ją na ekranie w kontekście pozostałych danych przestrzennych

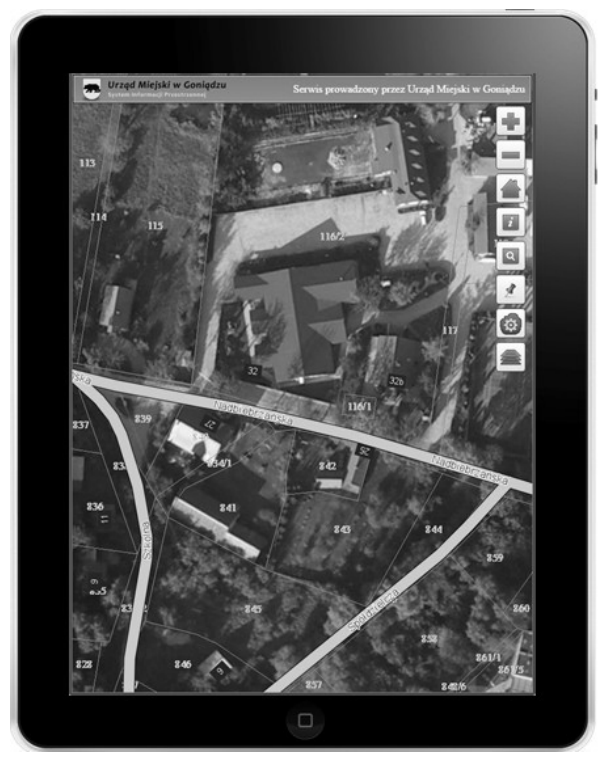

Rys. 8. Portal mapowy na urządzeniu mobilnym (tablecie)

Fig. 8. Example of using eGmina map portal on mobile device 
Użytkownicy zaawansowani systemu otrzymują dodatkowe mechanizmy rejestracji fotograficznej miejsc $\mathrm{z}$ automatycznym przypisaniem do funkcjonujących adresów. Może to być zdjęcie elewacji budynku, jak też zaewidencjonowanie pustostanu czy uszkodzonego ogrodzenia. Jak zawsze wykorzystanie narzędzi ograniczają jedynie czas i wyobraźnia.

Oczywiście potrzeba wykorzystania informacji adresowej w terenie nie jest jedynym odnotowanym i powtarzalnym wykorzystaniem rejestrów adresowych. Wspomniana wcześniej ewidencja ludności, poza umożliwieniem weryfikacji tego rejestru również zwrotnie czerpie informacje o nowo nadanych adresach. W gminach wykorzystujących system iMPA dobrą praktyką jest zameldowanie obywatela dopiero po potwierdzeniu funkcjonowania adresu przez pracownika odpowiedzialnego za numerację adresową. Udaje się w ten sposób uniknąć rozhermetyzowania wypracowanego porządku w ramach tych dwóch baz.

Kolejnym zastosowanie numeracji adresowej jest powiązanie jej z zarządzaniem odpadami komunalnymi. Od wejścia w życie nowych przepisów dotyczących organizacji gospodarki komunalnej i odpadów gminy w znacznym stopniu unowocześniły ten obszar zarządzania gminą. Zakupiono specjalistyczne oprogramowanie, uporządkowano sprawy związane z ewidencjonowaniem sposobu odbierania odpadów. Ale powiązanie tych informacji $\mathrm{z}$ przestrzenią możliwe jest dopiero $\mathrm{w}$ oparciu o punkty adresowe - w tym zakresie firma Geo-System Sp. z o.o. podjęła szereg działań skutkujących opracowaniem mechanizmów integracji bazy adresowej z systemami różnych producentów. Zebrane deklaracje i umowy są powiązane z punktem adresowym i wyświetlane dla pracowników urzędu za pośrednictwem aplikacji eGmina.

Z punktu widzenia zarządzania państwem i poszczególnymi procesami punkt adresowy i jego lokalizacja są bardzo istotne. Potwierdza to chociażby działanie Urzędu Komunikacji Elektronicznej, który w okresie od stycznia do marca 2015r. intensywnie zabiegał $\mathrm{w}$ gminach o udostępnienie aktualnej numeracji adresowej. Było to konieczne ze względu na podjęte kroki zmierzające do wykorzystania jak największej puli środków unijnych na zwiększenie dostępności internetowych łączy szerokopasmowych w wielu obszarach Polski. Brak prowadzonej w systemie teleinformatycznym i udostępnianej na bieżąco numeracji porządkowej mógł dyskwalifikować gminy, a dokładnej mieszkańców obszarów nieuwzględnionych w dotychczasowej infrastrukturze sieciowej.

Drugim aktualnym tematem jest problem $\mathrm{z}$ funkcjonowaniem Centrum Powiadamiania Ratunkowego (nr 112), które, zgodnie z monitem rozesłanym w czerwcu 2015r. przez Sekretarza Stanu MAiC Stanisława Huskowskiego do wojewodów, działa w oparciu o Uniwersalny Moduł Mapowy. W zakresie lokalizacji przestrzennej bazuje na rejestrze PRG. Wymienione w rozdziale 3 uwagi do funkcjonowania rejestru PRG mają potwierdzenie w praktyce. Mając na względzie problemy z samym mechanizmem zasilania PRG oraz bardzo niskim faktycznym wykorzystaniem przez gminy aplikacji GUGiK-EMUiA można jedynie wyobrazić sobie ogrom błędów nieścisłości i braków dotyczących 
adresów w narzędziach nawigacyjnych dla służb ratowniczych. Pewnym pocieszeniem może być fakt, że sprawy te nie dotyczą ponad 60\% gmin w Polsce, które korzystają z aplikacji internetowy Manager Punktów Adresowych.

\section{Wnioski}

Podstawowym wnioskiem z przeprowadzonej analizy może być stwierdzenie: jest dobrze, ale może być lepiej. Ocena stanu prowadzenia numeracji adresowej, bazując na 1500 wdrożeniach systemu iMPA w Polsce oraz analiza kontaktów z użytkownikami aplikacji GUGiK-EMUiA pokazuje, że z jednej strony prowadzenie rejestru na poziomie gminnych $\mathrm{w}$ strukturze rozproszonej stanowi wyzwanie technologiczne i organizacyjne, ale jednocześnie spełnia podstawowe oczekiwanie dostępu do informacji u źródła.

Niewątpliwie budowa baz adresowych w całej Polsce mogła być już zakończona, gdyby nie realizacja projektów GGK podporządkowanych wydatkowaniu środków unijnych i skupionych na oczekiwaniach władzy centralnej. Z perspektywy czasu widać, że próby zaangażowania się GUGiK w kwestie prowadzenia numeracji adresowej przyniosły paradoksalnie szkody w postaci obojętności wielu gmin w zakresie prowadzenia tego rejestru. Ponadto w odczuciu autorów wiele jednostek zamiast podjać działania przyjęło postawę wyczekiwania na efekty - w większości przypadków znacznie opóźnione - prowadzonych projektów, które niejednokrotnie nie są w stanie zaspokoić rosnących oczekiwań samorządów.

Należy przede wszystkim dalej budować w samorządach i u potencjalnych beneficjentów świadomość roli i ważności rejestru numeracji porządkowej. Tylko dzięki temu możliwe będzie doprowadzenie do końca procesu budowy baz adresowych prowadzonych na bieżąco $\mathrm{z}$ wykorzystaniem systemów teleinformatycznych.

W obliczu mnogości dofinansowanych z UE projektów realizowanych przez marszałków województw czy Głównego Geodetę Kraju należy zaapelować, aby nie przedkładano partykularnego interesu w promocji własnych działań nad potrzebę wsparcia merytorycznego samorządów gminnych w zakresie prowadzenia rejestrów referencyjnych, zwłaszcza numeracji adresowej. W ocenie autorów konieczne jest skupienie się na faktycznych i realnych efektach ewentualnych projektów zamiast na wskaźnikach, które niejednokrotnie są założone bez głębszej analizy i w efekcie determinują machinalne, nieprzemyślane działanie. 


\title{
Literatura
}

[1] Ustawa o infrastrukturze informacji przestrzennej z dnia 4 marca 2010r. (Dz.U. z 2010r. nr 76 poz. 489)

[2] Ustawa prawo geodezyjne i kartograficzne z dnia 17 maja 1989r. (Dz.U. z 2015 poz. 520)

[3] Rozporządzenie Ministra Administracji i Cyfryzacji w sprawie ewidencji miejscowości ulic i adresów z dnia 2 lutego 2012r. (Dz.U. z 2012r. nr 23 poz. 125)

[4] Izdebski W., Malinowski Z., Jak naprawić EMUiA, Magazyn Geoinformacyjny GEODETA, nr 5 (216), 2013, s. 24-28

[5] Rozporządzenie Rady Ministrów w sprawie państwowego rejestru granic i powierzchni jednostek podziałów terytorialnych kraju z dnia 10 stycznia 2012 (Dz.U. z 2012r. poz 199)

[6] Izdebski W., Dobre praktyki udziału gmin i powiatów w tworzeniu infrastruktury danych przestrzennych w Polsce, www.izdebski.edu.pl, Warszawa 2014

[7] Izdebski W., Koncepcja i wdrożenia technologii GEO-MAP, Oficyna Wydawnicza Politechniki Warszawskiej, Warszawa 2013

[8] Izdebski W., Firmy razem mogą więcej, Magazyn Geoinformacyjny GEODETA, nr 2 (225), 2014, s. 14-18

\section{ORGANIZATION AND USAGE ANALYSIS OF ADDRESS REGISTER AND ITS VALUE FOR SOCIETY AND GOVERNMENT}

\begin{abstract}
S u m m a r y
Places, Streets and Addresses Register is one of the most important reference records in the country. Distributed maintenance of the register is a guarantee of the emergence of information at its source, but on the other hand, puts the technological and organizational challenges that must be considered in the effective functioning of the registry in Poland. The more important - over time the interest in the address, especially its spatial location, increases in direct proportion to the popularization of GIS and GPS navigation, e.g. in emergency medical services, civil defense or in operations of many state institutions expecting a high-availability of the register for their own purposes. Public awareness in similar fashion increases year-on-year and with it grow the expectations of immediate availability of updated information on-line, also on mobile devices. This paper organizes and describes the current state of the address register with the indication of the challenges, issues and barriers to overcome and the basic areas of use in respect of the citizen activities, the functioning of central and local government authorities, and unusual uses that are formed over time as the dissemination of the address register as a basic spatial reference register, standing at least on a par with the land and buildings register. The proposals are based on extensive experience in the area of the practical functioning of the address register as result of the implementation of internetowy Manager Punktów Adresowych (Internet Address Point Manager) services in over 1,500 municipalities in Poland in the last few years by the GeoSystem Sp.z o.o.
\end{abstract}

Keywords: address, registry, EMUiA, GIS, navigation, map portal, administration, www.punktyadresowe.pl 
Przesłano do redakcji:10.08.2015

Przyjęto do druku:10.01.2016

DOI: $10.7862 / \mathrm{rb} .2015 .184$ 